\title{
AGRÁRÉLŐHELYEK ÍZELTLÁBÚ (ARTHROPODA) FAUNÁJÁNAK VIZSGÁLATA A LAJTA PROJECT TERÜLETÉN 2014-BEN
}

\author{
Kelemen Petra \\ Vadgazdálkodási és Gerinces Állattani Intézet \\ Nyugat-magyarországi Egyetem, Erdőmérnöki Kar \\ H-9400 Sopron, Bajcsy-Zsilinszky Endre utca 4.
}

\begin{abstract}
KELEMEN P. : INVESTIGATION ON THE ARTHROPODA FAUNA OF AGRICULTURAL HABITATS IN THE LAJTA PROJECT IN 2014. Hungarian Small Game Bulletin 12: 357-364. http://dx.doi.org/10.17243/mavk.2014.357

The aim of this study was to survey the Arthropod fauna in various intensive, extensive and unmanaged agricultural habitats in the LAJTA Project. Arhtropods were trapped using Barber's traps in 13 habitats from April to August 2014. A total of 20314 individuals belonging to 15 taxa were identified. Significant differences in Arthropod number were found between the differently managed habitats while no significant differences were detected in relation to Arthropod biomass.
\end{abstract}

KULCSSZAVAK: Arthropoda, LAJTA Project, mezőgazdasági intenzifikáció

KEYWORDS: Arthropoda, LAJTA Project, agricultural intensification

\section{BEVEZETÉS}

Hazánk területének 65,5\%-án folytatnak mezőgazdasági művelést (ÁNGYÁN et al., 2003). A mezőgazdaság intenzifikációja a nyugat európai országokban korábban elindult és nagyobb ütemben folyik, mint a volt szocialista kelet- és közép európai országokban. Részben ennek köszönhetően ezekben az országokban a mezőgazdasághoz kötődő fajok száma és abundanciája magasabb maradt (BÁLDI et al., 2005, DONALD et al., 2002, GREGORY et al., 2005). Hazánkban a mezőgazdasági intenzifikációja az 1950-es években kezdődött, amikor is a családi kis parcellás gazdálkodást a gépesített termőszövetkezetek váltották fel (ÁNGYÁN et $a l .$, 2001). A rendszerváltás után a mezőgazdasági termelés drasztikusan visszaesett (BÁLDI \& FARAGÓ, 2007). Magyarország Európai Unióhoz való csatlakozása, az agrár-élővilág szempontjából aggodalomra adott okot (DONALD et al., 2002). A biodiverzitás csökkenésének megállítására és visszafordítására több európai uniós országban agrár-környezetvédelmi programokat dolgoztak ki és hirdettek meg (KLEIJN \& SuTHERLAND, 2003, STOATE et al., 2001).

A szántóföldi termelés produktivitása érdekében nagyobb területeket azonos módon müvelnek (táblásítanak), amely a szántóföldi szegélyek csökkenését eredményezi (SzITÁR et al. 2007). A megnövekedett távolságokat sok esetben a talajfelszíni ízeltlábúak nem tudják áthidalni (IRMLER, 2003). A mezőgazdaság negatív hatásai közül kiemelkednek a vegyszerek (növényvédő szerek) okozta károk (SzITÁR et al., 2007). A növények esetében alkalmazott növényvédő szerek nem elég szelektívek, például a gabonaföldeken alkalmazott gyomirtók 
nem csak a kétszikü növényekre, hanem más növényekre és élőlénycsoportokra, valamint a magbankra is mérgezően hatnak (HADDAD et al., 2000, HUNYADI et al., 2000).

Az ízeltlábú közösségekre a növényzet strukturális elszegényedése negatív hatással van. A táplálékforrásként szerepet játszó virágos növények és gyomnövények visszaszorulása az ízeltlábú populációk nagymértékü csökkenéséhez és számos faj eltűnéséhez vezet (KEMP et al., 1990; OUIN et al., 2004; GoULSON et al., 2008).

Az ízeltlábú táplálék minőségének és mennyiségének negatív változása közvetetten jelentkezik a táplálékláncban (NEWTON, 2004, BRITSCHGI et al., 2006, TAYLOR et al., 2006). A növényborításban bekövetkezett változások kihatnak az ízeltlábúakra, ezen keresztül pedig a rovarfogyasztó közösségekre, valamint a madárpopulációkra (BENTON, 2002, DI GIULIO et al., 2001, VICKERY et al., 2001). A szántóföldek közösségeit számos tényező befolyásolja, ezek közül is a legfontosabbak a táblaméret, a terület heterogenitása, a használt kemikáliák és a nem müvelt területek aránya (CLOUGH et al., 2005).

Jelen kutatásban arra kerestem a választ, hogy a nagyüzemi mezőgazdasági müvelés alatt álló LAJTA Project területén milyen mennyiségben és minőségben áll rendelkezésre ízeltlábú táplálék az itt élő madárpopulációk számára, amelyek között védelem alatt álló fajok is szerepelnek.

\section{ANYAG ÉS MÓDSZEREK}

\subsection{Vizsgálati terület}

A vizsgálatokat a Mosoni-síkság déli határában fekvő, 3065 hektár kiterjedésü LAJTA Project területén végeztük. A régióban intenzív, nagyüzemi mezőgazdasági müvelés folyik, a vetésszerkezet évröl-évre változik (FARAGÓ, 2012). 2014-ben a szántóterületek nagysága 2810 ha volt, a vonalas élöhelyek hossza elérte 426201 métert. A termesztett növények időszakos változása miatt, a project munkatársai pontos vetésterület térképezést végeznek minden hónapban.

Vizsgálatainkat összesen 13 élöhely-típusban végeztük, amelyek az intenzifikáció mértéke szerint 3 nagyobb csoportot képeznek:

1. nagytáblás, intenzíven müvelt kultúrák (kukorica, repce, őszi búza, őszi árpa, facélia, mustár);

2. extenzív nem vegyszerezett vetésterületek (bíborhere, fümag és lucerna);

3. nem müvelt élőhelyek (árokpart, erdősáv, parlag, gyepes táblaszegély)

\subsection{Terepi felmérések}

Az élöhelyenkénti ízeltlábú felméréseket úgynevezett BARBER-féle talajcsapdákkal végeztük, ezek elhelyezkedését a vizsgálati területen az 1. ábra szemlélteti. Az alkalmazott csapdák 3 dl ürtartalmú, $8 \mathrm{~cm}$ szájátméröjü műanyagpoharak voltak. Ölőfolyadékként 70\%-os monoetilén-glikol oldatot használtunk. Minden mintavételi helyen 5 méterenként 5-5 talajcsapda müködött, a lehelyezett talajcsapdákból 304 szolgáltatott adatokat. A csapdák 2014. április 30. és augusztus 25. között müködtek, két hetes intervallumokban. A gyüjtött ízeltlábú egyedeket taxon szintig határoztuk meg, majd szárítószekrényben szárítottuk 85-90 ${ }^{\circ} \mathrm{C}$-on, 24 órán keresztül, ezután következett a száraz biomassza mérése. 


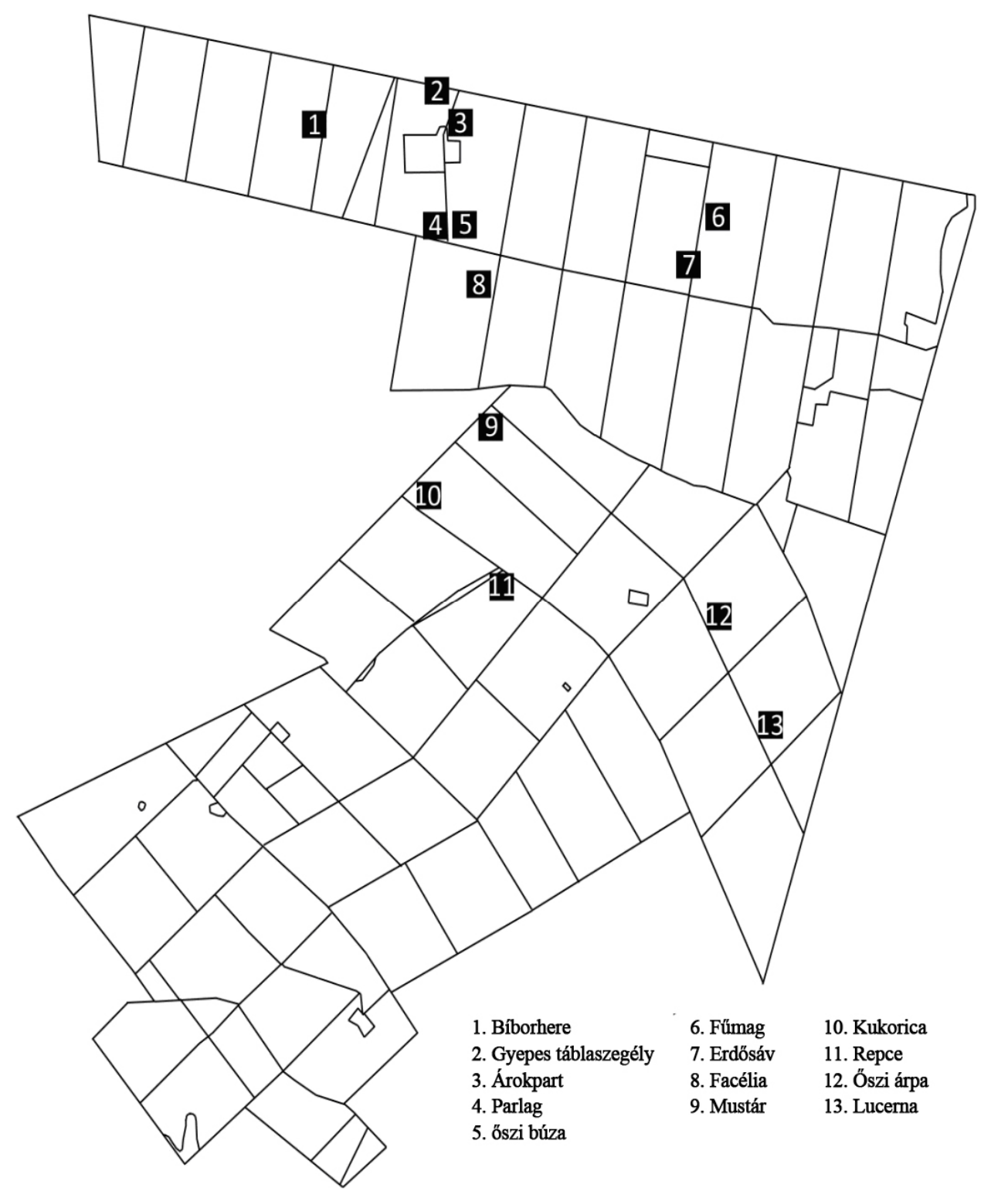

1. ábra: A Barber-féle talajcsapdák elhelyezkedése a LAJTA Project területén

Fig. 1: Placement of Barber-traps in the LAJTA Project

\subsection{A kiértékelés módszerei}

A statisztikai elemzésekhez páros t-tesztet, varianciaanalízist (ANOVA), a BRAY-CURTIS hasonlósági mérőszámon alapuló hierarchikus cluster-analízist, valamint a nem paraméteres elemzésekhez KRUSKAL-WALLIS tesztet alkalmaztam. A parametrikus próbák alkalmazhatóságának feltételeit minden esetben ellenőriztük. Az elemzéseket Past (HAMMER et $a l ., 1999)$ és SPSS Statistics 20.0 (SPSS, 2012) programcsomagokkal végeztük.

\section{EREDMÉNYEK ÉS MEGVITATÁS}

A vizsgálat során 15 taxon 20314 egyedét határoztuk meg. A talajcsapdák tartalmának nagyobb részét $(47,2 \%)$ a legyek (Diptera), a bogarak (Coleoptera - 28,31\%) és a hártyásszárnyúak (Hymenoptera - 13,04\%) rendjébe tartozó egyedek tették ki, míg a további taxonok kis 
százalékban jelentek meg (Arachnoidea - 3,11\%, Heteroptera - 1,92\%, Isopoda - 1,59\%, Dermatoptera - 1,51\%, Diplopoda - 1,30\%, Homoptera - 1,03\%, Orthoptera - 0,42\%, Lepidoptera - 0,27\%, Collembola - 0,22\%, Chilopoda - 0,01\%, Mantodea - 0,004\%).

A statisztikai elemzéseinkből kikerültek azok a taxonok, amelyek egyedszáma nem érte el az 5-öt az egyes mintavételi időpontokban. A Diptera rend kiugró értékei miatt szintén kikerült a statisztikai elemzésekböl.

A müvelt és nem művelt területek ízeltlábú faunájának különbözőségét a gyüjtött taxonok abundanciája és biomasszája alapján vizsgáltuk. A összes taxon egyedszáma alapján történő osztályozás során két csoport különült el egymástól (2. ábra). Megmutatkozik az intenzíven művelt területek elkülönülése az extenzív és nem művelt területektől. Kivételt képeznek azonban a fümaggal és kukoricával vetett területek, előbbi az intenzívebb kultúrákhoz sorolódott, míg utóbbi az extenzív ill. nem müvelt területekkel került egy csoportba. A varianciaanalízis szerint az egyedszám esetében a három élőhelycsoport szignifikánsan eltérnek egymástól (ANOVA, $d f=2 ; F=6,394 ; p<0,016$ ). A nem müvelt élőhelyek és a nagytáblás módon müvelt területek között szignifikáns a különbség (páros tteszt, $t=2,272 ; p<0,039)$, míg a nem müvelt és extenzív módon mủvelt területek (páros t-teszt, $t=1,982 ; p<0,062$ ), valamint a két mủvelési mód (páros t-teszt, $t=0,757 ; p<0,462$ ) között nem volt kimutatható eltérés az ízeltlábú abundancia alapján.

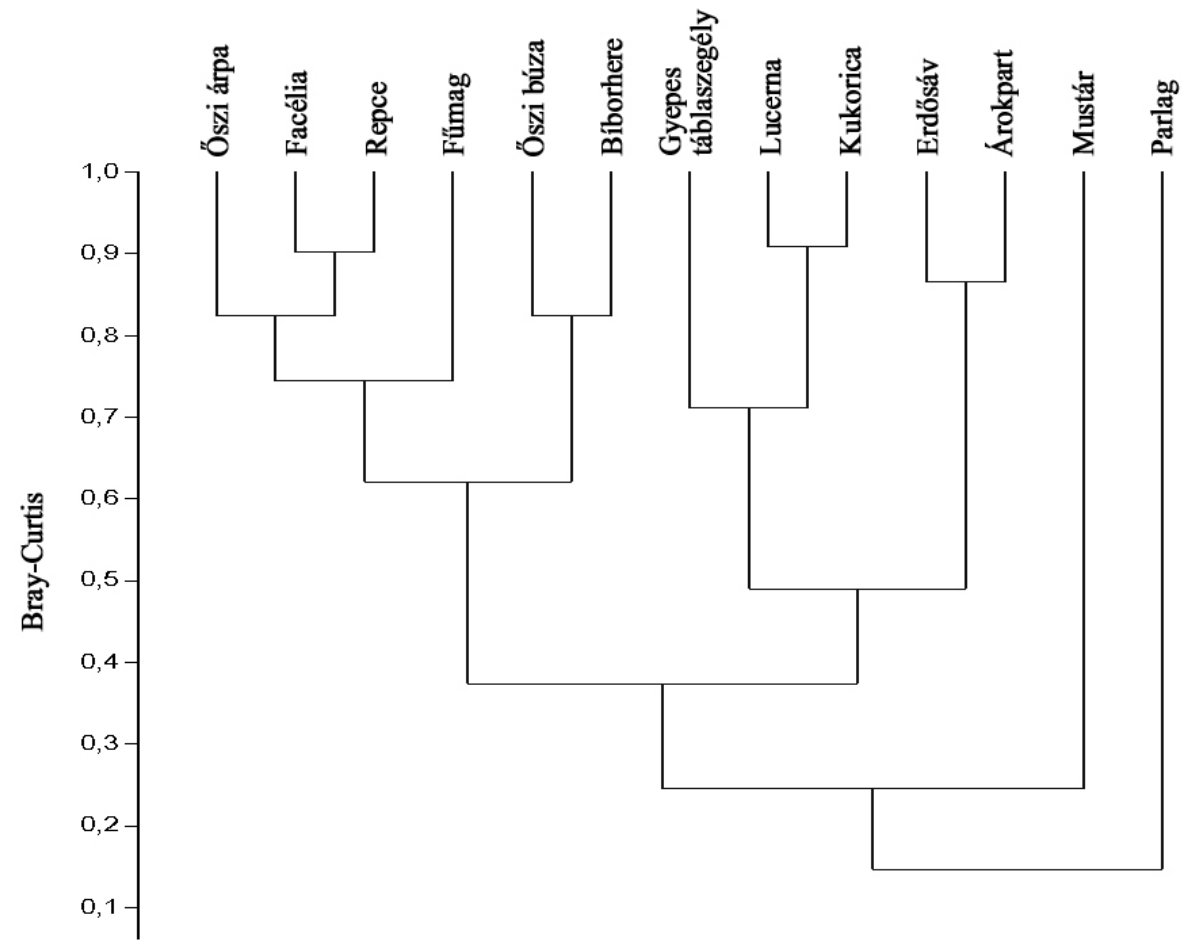

\section{2. ábra: Az ízeltlábú táplálékbázis egyedszámának hierarchikus klaszteranalízis során kapott dendrogamja}

Fig. 2: Dendrogram based on cluster analysis using Bray-Curtis index of similarity on the Arthropod number of individuals

Az összes taxon biomasszája alapján osztályozva a mintavételi területeket, a parlag vált el legélesebben (3. ábra), a talajcsapda által gyüjtött ízeltlábúak biomasszája itt volt a legmagasabb. Az ízeltlábú biomassza alapján végzett hierarchikus elemzés során az intenzifikáció mértéke szerint kialakított élőhely csoportok nem mutattak határozott elkülönülést, illetve a varianciaanalízis sem mutatott szignifikáns különbséget közöttük (ANOVA, $d f=2 ; F=3,606 ; p<0,006$ ). 


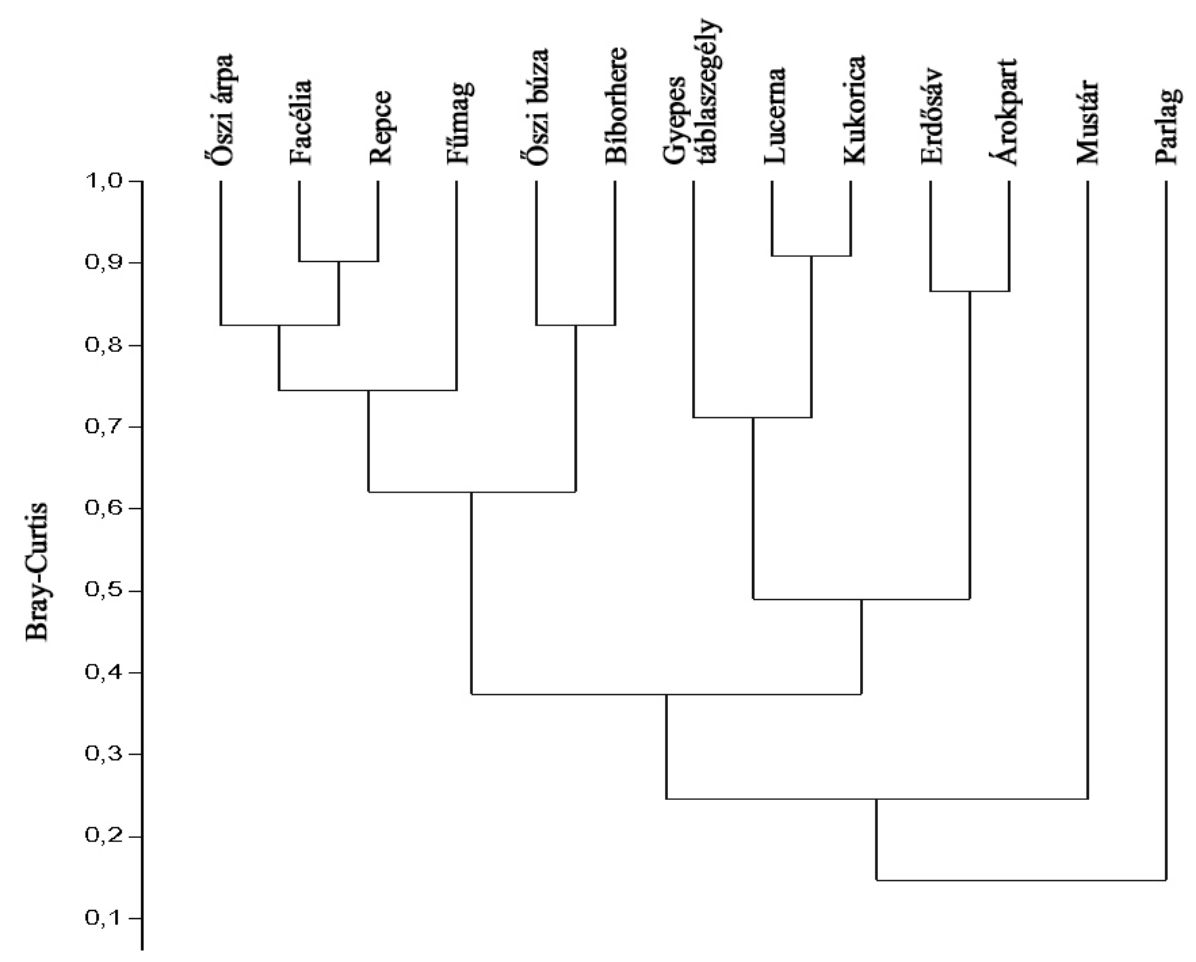

\section{3. ábra: Az ízeltlábú táplálékbázis biomasszájának hierarchikus klaszteranalízis során kapott dendrogamja}

Fig 3.: Dendrogram based on cluster analysis using BRAY-CURTIS index of similarity on the Arthropod biomass

A hónapokra (május, június, július és augusztus) összesített adatok között szignifikáns eltérés volt megfigyelhető egyedszám (KRUSKAL-WALLIS teszt, $H=8,935 ; p<0,029)$ valamint biomassza (KRUSKAL-WALLIS teszt, $H=8,679, \quad p<0,033)$ értékek alapján is. A szárnyasvadfajok táplálékaként fontos Coleoptera fajok egyedszáma szignifikánsan eltér a vizsgált élőhelycsoportoknál (ANOVA, $d f=2 ; F=11,787 ; p<0,003$ ), a biomassza alapján végzett elemzés viszont nem mutatott eltérést (ANOVA, $d f=2 ; F=1,892 ; p<0,206$ ) (4. ábra).
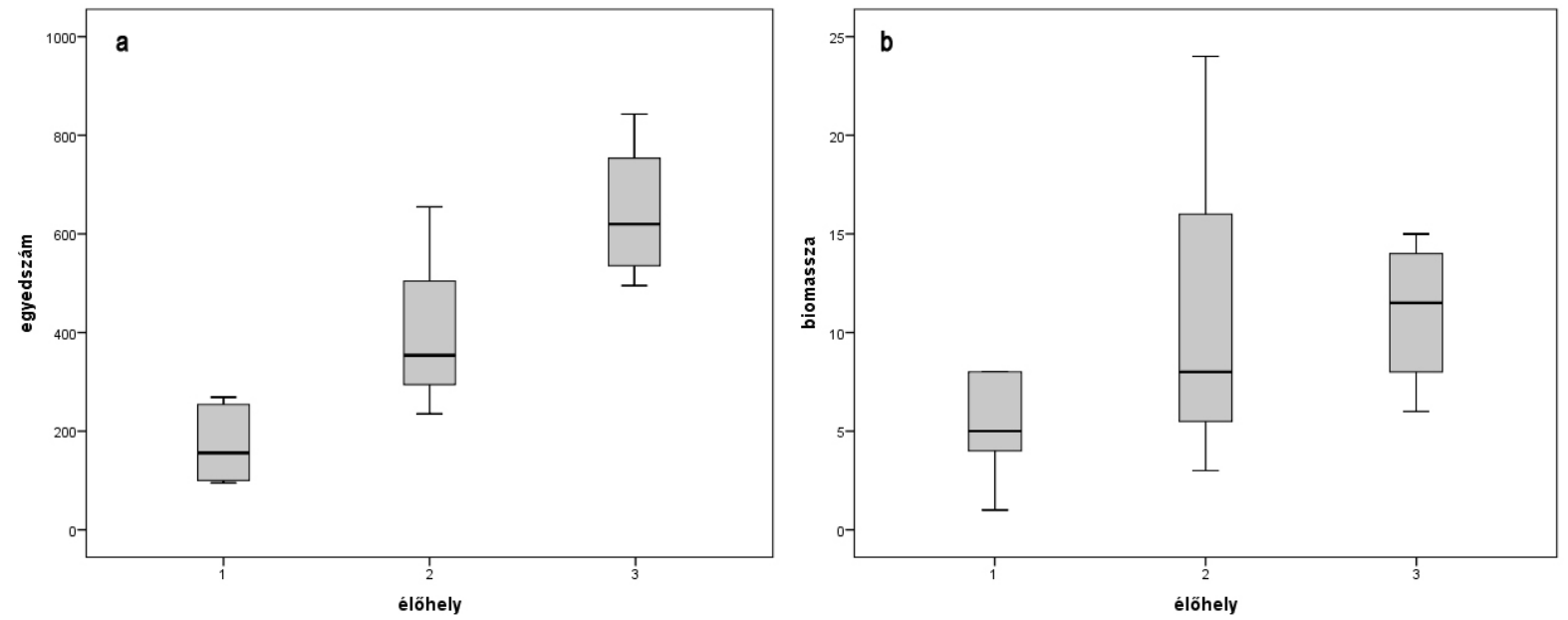

4. ábra: A Coleoptera egyedszám (a) és biomassza (b) eloszlása a különböző élőhelycsoportokban (1. intenzív, 2. extenzív, 3. nem müvelt)

Fig. 4: Coleoptera numbers (a) and biomass (b) range of variation in differently managed habitat groups (1. intensive, 2. extensive, 3 . unmanaged) 


\section{DISZKUSSZIÓ}

A szárnyasvadfajok számára fontos tényező az Arthorpoda táplálékkínálat mennyisége és minősége (FARAGÓ, 1990). A szaporodási és fióka nevelési időszakban lényeges a táplálékforrás fehérjetartalma (HOLLAND et al., 2006, WILSON et al., 1999). A gyüjtött ízeltlábúak egyedszáma és biomassza tömegük különbözőséget mutattak az egyes mintavételi időpontok között. A májusi és júniusi mintákban az Arthropoda egyedszám és biomassza tömeg magasabb volt, amely azért fontos, mert a csibék táplálékát az első néhány hétben az egyes rovar csoportok teszik ki (FARAGó, 1990). A bogarak (Coleoptera) táplálékbázisban való szerepét külön vizsgáltuk, mivel a szárnyasvadfajok állati táplálékának nagyobb hányadát teszik ki (FARAGÓ, 1990). A vizsgált élőhely csoportok Coleoptera egyedszáma eltért egymástól, a bogarak mennyisége magasabb a kevesebb területet kitevő természetközeli, nem müvelt élőhelyeken. Eredményeink egybevágnak azzal a megállapítással, hogy a vegyszeres kezelések a táblák belsejében fajszám- és egyedszám csökkenést eredményeznek (WAGNER \& EDWARDS, 2001). A szántóföldek között elhelyezkedő gyepsávok, erdősávok táplálékot és menedéket nyújtanak az ízeltlábúak számára (SOTHERTON, 1984, PFIFFNER \& LUKA, 2000) és így könnyedén átterjedhetnek a környező müvelt területekre (TOPPING, 1999). A természetközeli élőhelyek megőrzésével és mozaikosabb tájszerkezet kialakításával hozzájárulhatunk a mezőgazdasági területek Arthropoda diverzitásának fenntartásához.

\section{5. ÖSSZEGZÉS}

A kutatás a mezőgazdasági területek ízeltlábú faunájának térbeli és időbeli változására irányult. Kimutattam, hogy az egyes élőhely-típusok ízeltlábú abundanciájában statisztikailag különbség van, de biomassza mennyiségükben ez nem mutatkozott meg. A nagytáblás müvelésü, intenzív és a nem müvelt élőhelyek Arthropoda egyedszáma nagymértékben különbözött viszont az extenzíven müvelt, vegyszermentes táblák és a nem müvelt területek ízeltlábú faunája nem tért el egymástól, amely arra enged következtetni, hogy ezek az élöhelyek számukra kedvező életfeltételeket nyújtanak. Az elemzés során az intenzív és extenzív müvelés alatt álló területek között szignifikáns eltérést sem az ízeltlábú egyedszám, sem a biomassza alapján nem sikerült kimutatni.

\section{KÖSZÖNETNYILVÁNÍTÁS}

Köszönettel tartozom DR. FARAGÓ SÁNDORnak a kutatás feltételeinek biztosításáért, NÉMETH TAMÁs MÁRTONnak a terepi munkában nyújtott segítségért. Köszönöm DR. WINKLER DÁNIELnek a hasznos megjegyzéseket, javaslatokat és szakmai támogatását. A kutatás az AGRÁRKLÍMA.2 VKSZ_12-1-2013-0034 pályázati projekt támogatásával valósult meg.

\section{IRODALOMJEGYZÉK}

ÁngyÁn J., PodmaniczKy L., SZABÓ M. \& VAJNÁNÉ M. A. (szerk.) (2001): Az Érzékeny Természeti Területek (ÉTT) rendszere. Tanulmányok Magyarország és az Európai Unió természetvédelméről. „EU-training for Nature Conservation Officials”. ELTE-TTK - SZIEKGI - KöM-TvH - TEMPUS kiadás, Budapest-Gödöllő-Berlin-Madrid-Thessaloniki. 69 p. 
ÁNGYÁN J., TARDY J. \& VAJNÁNÉ-MADARASSY A. (szerk.) (2003): Védett és érzékeny természeti területek mezögazdálkodásának alapjai. Mezőgazda kiadó, Budapest. 628 pp.

BÁLDI A., BATÁRY P. \& ERDÖS S. (2005): Effects of grazing intensity on bird assemblages and populations of Hungarian grasslands. Agriculture, Ecosystems and Environment 108: 251-263. http://dx.doi.org/10.1016/j.agee.2005.02.006

BÁLDI A. \& FARAGÓ S. (2007): Long-term changes of farmland game populations in a post-socialist country (Hungary). Agriculture, Ecosystems and Environment, 118: 307-311. http://dx.doi.org/10.1016/j.agee.2006.05.021

Benton, T. G. , BRYANT, D. M. , COLE L. \& CRICK H. Q. P. (2004): Linking agricultural practice to insect and bird populations: a historical study over three decades. Journal of Applied Ecology 39: 673-687. http://dx.doi.org/10.1046/j.1365-2664.2002.00745.x

BRITSCHGI, A., SPAAR, R. \& ARLETTEZ, R. (2006): Impact of grassland farming intensification on the breeding ecology of an indicator insectivorous passerine, the Whinchat Saxicola rubetra: Lessons for overall Alpine meadowland management. Biological Conservation 130: 193-205. http://dx.doi.org/10.1016/j.biocon.2005.12.013

Clough, Y., Kruess, A., Kleijn, D. \& TscharntKe, T. (2005): Spider diversity in cereal fields: comparing factors et local, landscape and regional scales. J. Biogeogr. 32: 2007-2014. http://dx.doi.org/10.1111/j.1365-2699.2005.01367.x

Di Giulio, M., EDWARDS, P. J. \& MeISTER, E. (2001): Enhancing insect diversity in agricultural grasslands: the roles of management and landscape structure. Journal of Applied Ecology 38: 310-319. http://dx.doi.org/10.1046/j.1365-2664.2001.00605.x

Donald, P. F., PISANO, G., RAYMENT, M. D. \& PAIN, D. J. (2002): The Common Agricultural Policy, EU enlargement and the conservation of Europe's farmland birds. Agriculture, Ecosystems and Environment 89: 167-182. http://dx.doi.org/10.1016/S0167-8809(01)00244-4

FARAGÓ S. (1990): Vizsgálatok a szárnyasvad állati eredetű táplálékbázisáról mezőgazdasági környezetben Magyarországon. I. A szárnyasvad tápláléka, a táplálékbázis-vizsgálatok anyaga és módszere. EFE Tud. Közl. 1989 (2): 153-192.

FARAGÓ S. (1990): Vizsgálatok a szárnyasvad állati eredetủ táplálékbázisáról mezőgazdasági környezetben Magyarországon II. Mosonszolnok (Kisalföld). EFE Tud. Közl. 1989 (2): 193308.

FARAGÓ, S. (szerk.) (2012): A LAJTA Project. Egy tartamos mezei vad és ökoszisztéma vizsgálat 20 éve. Nyugat-magyarországi Egyetem Kiadó, Sopron. 636 p.

Gregory, R. D., VAN STRIEN, A., VORISEK, P., GMElig MEYling, A. W., NOBle D. G., FopPens R. P.B. \& GibBons, D. W. (2005): Developing indicators for European birds. Philosophical Transactions of Royal Society B 360: 269-288.

Goulson, D., Lye, G. C. \& DARVILl, B. (2008): Decline and conservation of bumblebees. Annual Review of Entomology 53: 191-208. http://dx.doi.org/10.1146/annurev.ento.53.103106.093454

HADDAD, N.M., HAARSTAD, J. \& TILMAN, D. (2000): The effects of long-term nitrogen loading on grassland insect communities. Oecologia 124: 73-84. http://dx.doi.org/10.1007/s004420050026

HAMMER, ̌̌., HARPER, D.A.T. \& RYAN, P.D. (2001) PAST: Paleontological statistics software package for education and data analysis. Palaeontologia Electronica 4(1): 9 p.

HUNYADI K., BÉRES I. \& KAZINCZI G. (szerk.) (2000): Gyomnövények, gyomirtás, gyombiológia. Mezőgazda Kiadó, Budapest. 338-339,384-385,399 pp.

IRMLER U. (2003): The spatial and temporal pattern of carabid beetles on arable fields in northern Germany (Schleswig-Holstein) and their value as ecological indicators. Agriculture, Ecosystems and Environment 98: 141-151. http://dx.doi.org/10.1016/S0167-8809(03)00076-8

KEMP, W.P., HARVEY, S.J., O'NEILL, K.M. (1990): Patterns of vegetation and grasshopper community composition. Oecologia 83: 299-308. http://dx.doi.org/10.1007/BF00317552

KLEIJN, D. \& SuTHERLAND, W. J. (2003): How effective are European agri-environment schemes in conserving and promoting biodiversity? Journal of Applied Ecology 40: 947-969. http://dx.doi.org/10.1111/j.1365-2664.2003.00868.x

NEWTON, I. (2004): The recent declines of farmland bird populations in Britain: an appraisal of causal factors and conservation actions. Ibis 146: 579-600. http://dx.doi.org/10.1111/j.1474919X.2004.00375.X 
Ouin, A., AVIRON, S., Dover, J. \& Burel, F. (2004): Complementation/supplementation of resources for butterflies in agricultural landscapes. Agriculture, Ecosystems and Environment 103: 473479. http://dx.doi.org/10.1016/j.agee.2003.11.003

PFIFFNER, L. \& LUKA, H. (2003): Effects of low-input farming systems on carabids and epigeal spiders - a paired farm approach. Basic and Applied Ecology 4: 117-127. http://dx.doi.org/10.1078/1439$1791-00121$

SOTHERTON, N. W. (1984): The distribution and abundance of predatory arthropods overwintering on farmland. Annals Applied Biology 105: 423-429. http://dx.doi.org/10.1111/j.17447348.1984.tb03068.x

SPSS (2012): SPSS Base 20.0. SPSS Incorporation, Chicago.

Stoate, C., Boatman, N. D., Borralho, R. J., Rio Carvalho C., De Snoo G. R. \& Eden P. (2001): Ecological impacts of arable intensification in Europe. J. Environ. Management 63: 337-365. http://dx.doi.org/10.1006/jema.2001.0473

SzITÁr, K. \& HORVÁTH, A. (2007): A mezőgazdaság intenzifikációja. In: HoRVÁTH A. \& SzITÁr K. (szerk.): Hazai agrártájak természetközeli vegetációjának monitorozása. Miért monitorozzuk az agrártájak vegetációját? MTA ÖBKI, Vácrátót. pp. 47-54.

TAYLOR, R.L., MAXWELL, B.D. \& BOIK, R.J. (2006): Indirect effects of herbicides on bird food resources and beneficial arthropods. Agriculture, Ecosystems and Environment 116: 157-164. http://dx.doi.org/10.1016/j.agee.2006.01.012

TOPPING, C. J. (1999): An individual-based model for dispersive spiders in agroecosystems: simulations of the effects of landscape structure. The Journal of Arachnology 27: 378-386.

Vickery, J. A., Tallowin, J. R., Feber, R. E., Asteraki, E. J., Atkinson, P. W., Fuller, R. J. \& BROWN, V. K. (2001): The management of lowland neutral grasslands in Britain: effects of agricultural practices on birds and their food rescources. Journal of Applied Ecology 38: 647664. http://dx.doi.org/10.1046/j.1365-2664.2001.00626.x

WAGNER, H. H. \& EDWARDS, P. J. (2001): Quantifying habitat specificity to assess the contribution of a patch to species richness at a landscape scale. Landscape Ecology 16: 121-131. http://dx.doi.org/10.1023/A:1011118007670

Wilson J. D., Morris A. J., ARroyo B. E., Clark S. C. \& Bradbury R. B. (1999): A review of the abundance and diversity of invertebrate and plant foods of granivorous birds in northern Europe in relation to agricultural change. Agriculture, Ecosystems and Environment 75:13-30. http://dx.doi.org/10.1016/S0167-8809(99)00064-X 